\title{
Resource Utilisation and Curriculum Implementation in Community Colleges in Kenya
}

\author{
Peter Changilwa Kigwilu*1 and Winston Jumba Akala ${ }^{2}$ \\ ${ }^{1}$ United States International University-Africa, Box 14634-00800, Nairobi, Kenya \\ ${ }^{2}$ School of Education, University of Nairobi, Box 92-00902, Kikuyu, Kenya
}

Received: 12.04.2017; Accepted: 23.10.2017; Published: 21.12.2017

\begin{abstract}
The study investigated how Catholic-sponsored community colleges in Nairobi utilise the existing physical facilities and teaching and learning resources for effective implementation of Artisan and Craft curricula. The study adopted a mixed methods research design. Proportional stratified random sampling was used to sample 172 students and 18 teachers while four directors of community colleges were purposively selected. Questionnaires were administered to students and teachers, while directors were interviewed. Teaching and learning resources, such as workshops, equipment, lecture rooms, laboratories, raw materials for practical training and reference books, were found to be adequate, although underutilised. However, sports grounds, libraries and course texts were inadequate. Resource inadequacies were often mitigated by signing equipment co-sharing agreements with peer institutions and local firms. Teachers rated highly the influence of physical facilities on curriculum implementation. Both students and teachers rated highly the influence of teaching and learning resources on curriculum implementation. The study concludes that, while some physical facilities and teaching and learning resources are adequate, their underutilisation and the inadequacy of other core facilities and resources, such as libraries and course textbooks, hinder effective teaching and learning in these community colleges.
\end{abstract}

Keywords: VET, Vocational Education and Training, Artisan and Craft, Community Colleges, Curriculum Implementation, Resource Utilisation

*Corresponding author: pchangilwa@gmail.com

ISSN: $2197-8646$

http://www.ijrvet.net 


\section{Introduction: Background and Significance of the Study}

The realisation of Kenya's Vision 2030 is anchored on the provisions for quality education and training through Technical and Vocational Education and Training (TVET), which has emerged as an effective human capital development strategy for empowering a technical workforce for rapid industrialisation and national development (Afeti, 2014; Republic of Kenya, 2012a). As such, Kenya emphasises the relevance of TVET in meeting the needs of the labor market by preparing students for work, productivity and competitiveness (African Union, 2007; Korpi, De Graaf, Hendrick, \& Layte, 2003). Despite the significance of the sector in spurring growth, issues of insufficient pedagogically competent trainers, inadequate centers, low enrolment, limited customised teaching and learning materials and expensive equipment hinder attainment of this goal (Republic of Kenya, 2012b). Consequently, many TVET students acquire low quality training, thereby limiting their prospects of becoming self-reliant and productive in the labour market (Onsomu, Wambugu, \& Wamalwa, 2009).

Global and local studies on the factors influencing effective implementation of TVET programs demonstrate a superficial interrogation of some of these factors. For instance, most studies lack specificity on the adequacy of facilities and resources (Ayuba \& Gatabazi, 2010; Hooker et al., 2011; Mupinga, Busby, \& Ngatiah, 2006; UNESCO, 2010). More specifically, little empirical evidence exists on Artisan and Craft curriculum implementation thereby creating a dearth of literature in this area. This paper has been adapted from the author's doctoral dissertation, which investigated the determinants of effective implementation of Artisan and Craft courses in Catholic-sponsored community colleges in the Nairobi region (Kigwilu, 2014). In particular, the paper investigates how Catholicsponsored community colleges in the Nairobi region utilise the existing physical facilities and teaching and learning resources to enhance effective implementation of Artisan and Craft curricula. The study sought to answer the following research questions:

i How do community colleges utilise physical facilities for effective implementation of Artisan and Craft curricula?

ii How do community colleges utilise teaching and learning resources for effective implementation of Artisan and Craft curricula?

The findings of the study will be useful in a number of ways. Firstly, they will assist the Ministry of Education in making policy decisions on resource allocations to TVET institutions to enhance education and training quality. Secondly, community colleges and other TVET institutions will, based on the findings, adopt measures that will optimise the available resources for effective teaching and learning. Thirdly, given the paucity of extant research on this topic, the findings will enrich the literature on education provisions in community colleges in Kenya, offering a valuable resource for use by scholars and practitioners with a focus on Artisan and Craft curricula. 


\section{Literature Review and the Adopted Research Framework}

First and foremost, quality education hinges on physical facilities that are the ultimate predictors of students' academic achievements (Yara \& Otieno, 2010; Moochi, 2012). Indeed, several studies show that inadequacy of infrastructure, facilities and equipment affects curriculum implementation in TVET institutions (Hooker et. al., 2011; Indoshi, Wagah, \& Agak, 2010; Mupinga, et al., 2006; Ayuba \& Gatabazi, 2010). Furthermore, reliance on obsolete equipment compromises effective training of youth for a modern economy (UNESCO, 2010). While Indoshi, et al. (2010) observe that vocational schools lack materials, equipment and facilities that are vital for effective teaching and learning, Ayuba and Gatabazi (2010) link the inadequacy of these facilities to inadequate finances in the institutions. Inadequate finances, in turn, shrink the budgets for procuring upto-date tools and equipment, repairing old equipment and developing training materials (Sharma, 2008). This is echoed in the Taskforce Report (2012) on education in Kenya, which finds that the high costs of training materials and text books, the inadequate physical facilities and the insufficient availability of modern equipment in most TVET institutions adversely affects curriculum implementation. The cited studies point to the inadequacy of many facilities in TVET institutions. On the contrary, Simiyu (2009) established that Kaiboi Technical Training Institute had adequate facilities - namely workshops, laboratory space and machines. Moreover, Messah and Mucai (2011) posit a positive correlation between the adequacy of an institutionâẮzs finances and the provisions of that institutionâẮ́s physical facilities, a position supported by Hicks, Kremer, Mbiti and Miguel (2011). The inverse correlation, though, would emphasise that inadequate finances and inadequate physical facilities ultimately provide fewer opportunities for students to practice with tools and machines, hence negatively impacting student outcomes.

Second, inadequacy of teaching and learning resources is a constraint to implementation of TVET in public institutions (Hailu, 2011). In particular, a lack of standard workshops and modern instructional materials affects the teaching of TVET (Bandele \& Faremi, 2012). A corollary effect is the low acquisition of practical skills among students due to ineffective instructional delivery (Dasman, 2011). In many developing nations, inadequate curriculum resources and outdated equipment hinder effective implementation of training and teaching programs (Maino, 2013). In actual fact, teachers' utilisation of relevant equipment, materials and tools in teaching facilitates learning and enhances students' achievements (Umunadi, 2012). However, in most of these nations, instructional materials are inadequate for effective teaching in TVET institutions (Wondaferew, 2012).); such institutions may have insufficient equipment and lack specialist rooms for practical teaching (Tshabalala Ncube, 2014). Similarly, in Kenya, inadequacy of teaching and learning resources hinders TVET implementation (Indoshi, et al., 2010). This inadequacy is expressed in terms of obsolete equipment (Hooker et. al, 2011), shortage of material resources (Indoshi, et al., 2010; Mupinga, et al., 2006) and insufficient time allocation (Indoshi, et al., 2010). Automobile engines, sewing machines, computers, computer software, textbooks, stationery and internet access are among the resources that are most often inadequate or unavailable (Mupinga et al., 2006). 
Finally, the reviewed studies, except those by Mupinga et al. (2006) and Simiyu (2009), lack specificity regarding the physical facilities or teaching and learning resources that affect curriculum implementation. Neither do they describe the levels of adequacy and utilisation of these facilities and teaching and learning resources in TVET institutions. Moreover, the cited studies have been either purely quantitative or purely qualitative in approach, lacking triangulation of the two approaches. These are the empty spaces that the current study focused on filling.

Figure 1 shows the adopted research framework. The framework presents physical facilities and teaching and learning resources as the inputs in the curriculum implementation process. The inputs interact with content, teaching and learning process, assessment and support services in order to yield the intended educational outputs namely syllabus coverage, employability skills and life-long skills.

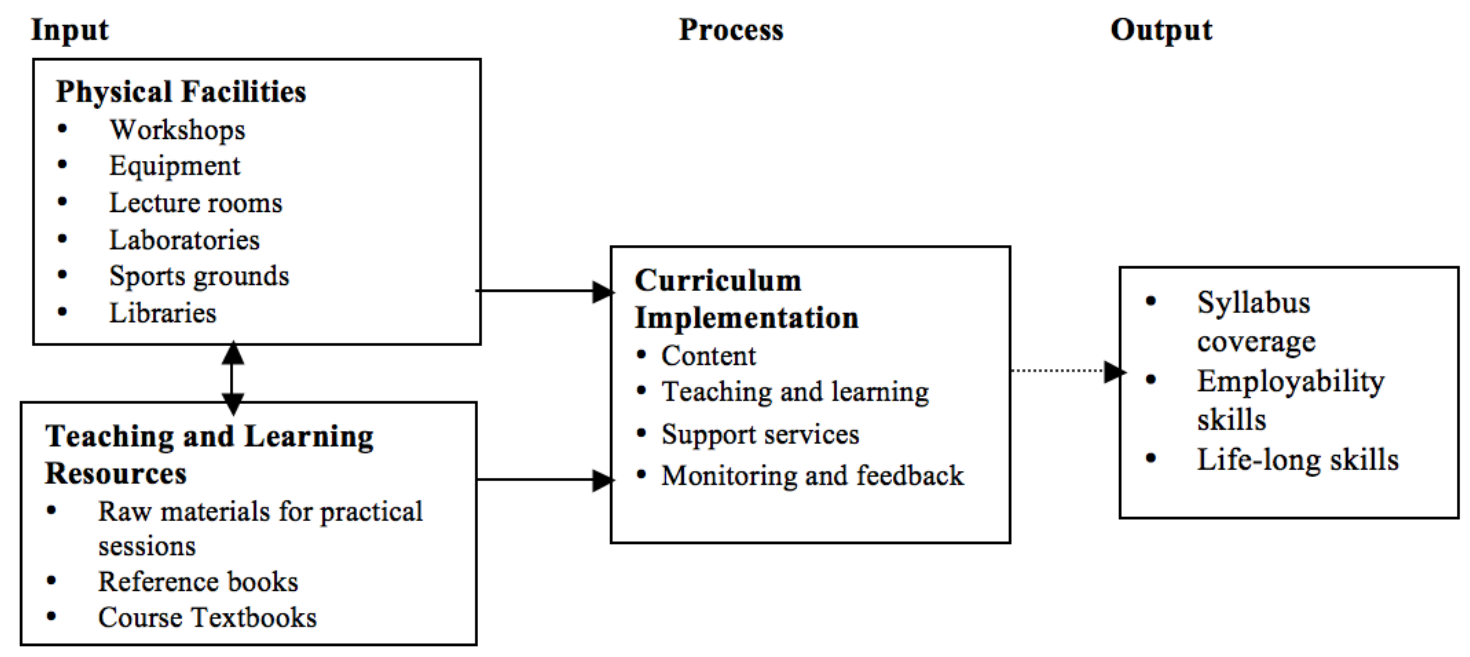

Figure 1: Resources and Curriculum Implementation

As discussed in the foregoing literature (e.g. Bandele \& Faremi, 2012; Umunadi, 2012; Tshabalala \& Ncube, 2014), relevant equipment, materials and tools such as workshops laboratories, lecture rooms course and reference texts are required in the teaching and learning process to yield the intended educational outputs. For instance, the textbooks are useful in development of instructional content and the rooms (workshops, laboratories and lecture rooms) provide supported environment in which learners interact with the content to achieve the intended educational outputs namely syllabus coverage, acquisition of employability skills and life-long skills. The framework holds that both the physical facilities and the teaching and learning resources mutually act together to influence the quality of curriculum implementation. Further, the framework views curriculum implementation as an interplay of content, teaching and learning process, provision of support services, and monitoring and feedback activities in order to achieve the intended educational outputs (Ebenehi, Rashid, \& Bakar, 2016). Therefore, the Utilisation of these 
physical facilities and teaching and learning resources in the curriculum implementation process eventually determines the kind of outputs of the educational process.

\section{Methods and Instruments}

This section presents the design adopted for the study, description of the research participants, the administration and validation of research instruments, and data analysis and ethical considerations that guided the study.

\subsection{Design}

The study adopted mixed methods research design. Data were gathered through crosssectional survey design. Survey research design was used to describe, explain or explore the existing status of and relationships between variables at a given time.

\subsection{Participants}

The target population comprised 331 students, 25 teachers and four directors of the community colleges. The teachers were full-time staff with at least six month's stay in the community colleges. Proportional stratified random sampling was used to select students and teachers from each of the four community colleges. All four directors of community colleges were purposively included in the sample since they were believed to have in-depth understanding of the operations of community colleges. Bartlett, Kotrlik, and Higgins (2001) recommend sample sizes of 169 and 196 for populations of 300 and 400 respectively at margin of error of 0.05 . However, since oversampling is recommended to make up for shortfalls between the expected and actual sample size reached, the study sampled 194 participants: 172 students, 18 teachers and four directors of community colleges sampled for the study.

The students' sample comprised $53.4 \%$ and $46.6 \%$ of male and female students respectively, relative to their enrolment in courses in the sampled community colleges. Out of the sampled teachers, $55.6 \%$ were male and the remaining $44.4 \%$ were female teachers. In terms of age, $89.7 \%$ of both male students and female students were in 16-25 age bracket. Although there was mean age parity for male students and female students, more age variations existed among female students $(\mathrm{M}=21.4 ; \mathrm{SD}=4.1)$ than male students $(\mathrm{M}=21.4 ; \mathrm{SD}=3.8)$.

The mean age of 21.4 is considered normal since students completing secondary education in Kenya usually transit to post-secondary institutions at ages slightly above 18. The teachers were generally youthful $(70.0 \%$ male teachers and $62.5 \%$ female teachers were in 20-35 age bracket) but with fairly large age gaps $(\mathrm{M}=33.3, \mathrm{SD}=8.3)$. This implies that on average, the teachers were at various career growth stages hence likely to bring on board their new and existing knowledge and experiences to create a versatile teaching force for effective implementation of Artisan and Craft courses. 


\subsection{Instrument Administration and Validation}

Questionnaires and in-depth interview guides were used to collect data. Instrument triangulation strengthened the study by compensating for weaknesses of either instrument (Punch, 2009). Other than questions seeking demographic information and open-ended questions in the questionnaire, all other questions were in form of three-point or fivepoint rating scales. Both teachers' and students' questionnaires solicited background information, information on adequacy of physical facilities, and teaching and learning resources, and how they influenced implementation of Artisan and Craft curriculum. The interviews sought detailed information from each director.

The questionnaires were piloted to 28 students and five teachers in three community colleges within Nairobi region. The instruments were content-and face-validated by subjecting them to thorough scrutiny from experts in curriculum studies and specialists in Artisan and Craft courses. The instruments had an acceptable internal consistency (Cronbach's alpha statistic of 0.72 and 0.73 for teachers' questionnaire and students' questionnaires respectively).

\subsection{Data Analysis and Ethical Considerations}

Quantitative data were analyzed using descriptive statistics such as frequencies, percentages, means and standard deviations. Qualitative data were carefully transcribed as soon as they were recorded from the field, edited, ambiguities removed, and coded into themes that emerged from the responses. The transcribed data were cross-checked against the audio recordings before undertaking a preliminary analysis of key issues emerging from the interviews. Analyzed data were then presented in form of narratives and excerpts. The study adapted the acceptable research ethics; the researchers obtained a research permit from the National Council of Science and Technology (Kenya), sought consent of the directors of the community colleges, teachers and students and assured them that the confidentiality of data, anonymity, their privacy and safety would be observed and maintained.

\section{Findings and Discussion}

This section presents and discusses the findings of the study based on the two research questions of the study.

\subsection{Utilisation of Physical Facilities in Curriculum Implementation}

In order to determine the Utilisation levels of physical facilities in the community colleges, students first rated this adequacy as very inadequate (1), inadequate (2), moderately adequate (3), adequate (4) and very adequate (5). Upon computing mean ratings, the facilities were rated as very inadequate $(1.0 \leq \mathrm{M} \leq 1.7)$, inadequate $(1.8 \leq \mathrm{M} \leq 2.5)$, moderately adequate $(2.6 \leq 3.3)$, adequate $(3.4 \leq \mathrm{M} \leq 4.1)$ and very adequate $(4.2 \leq$ 5.0). The results are presented in Table 1. 
Table 1: Students' Ratings of Adequacy of Physical Facilities

\begin{tabular}{lccccccccccc}
\hline Facility & VA & \multicolumn{3}{c}{ A } & \multicolumn{4}{c}{ MA } & \multicolumn{1}{c}{ I } & \multicolumn{3}{c}{ VI } & M \\
& f & \% & f & \% & f & \% & f & \% & f & \% & \\
\hline Workshops & 46 & 31.5 & 24 & 16.4 & 40 & 27.4 & 20 & 13.7 & 11 & 7.5 & 3.52 \\
Equipment & 46 & 31.5 & 35 & 24.0 & 26 & 17.8 & 15 & 10.3 & 20 & 13.7 & 3.51 \\
Lecture rooms & 31 & 21.2 & 32 & 21.9 & 21 & 14.4 & 23 & 15.8 & 32 & 21.9 & 3.05 \\
Laboratories & 15 & 12.5 & 35 & 29.2 & 12 & 10.0 & 14 & 11.6 & 44 & 36.7 & 2.69 \\
Sports grounds & 25 & 17.1 & 17 & 11.6 & 16 & 11.0 & 26 & 17.8 & 56 & 38.4 & 2.49 \\
Libraries & 13 & 8.9 & 13 & 8.9 & 26 & 17.8 & 26 & 17.8 & 59 & 40.0 & 2.23 \\
\hline
\end{tabular}

Note: $\mathrm{VA}=$ Very Adequate; $\mathrm{A}=$ Adequate; $\mathrm{MA}=$ Moderately Adequate; $\mathrm{I}=$ Inadequate; $\mathrm{VI}=$ Very Inadequate; $\mathrm{M}=$ Mean

The findings in Table 1 show that workshops and equipment were adequate $(\mathrm{M}=3.52$ and $\mathrm{M}=3.51$ respectively). Lecture rooms and laboratories $(\mathrm{M}=2.69)$ were moderately adequate $(\mathrm{M}=3.03$ and $\mathrm{M}=2.49$ respectively) whereas sports grounds and libraries were inadequate $(\mathrm{M}=2.49$ and $\mathrm{M}=2.23$ respectively). When interviewed, one of the community college directors clarified that physical facilities were adequate relative to student enrolment. The college pegged enrolment on available facilities as echoed in the following excerpt:

We have equipped our college with modern facilities and equipment to prepare our students adequately for the job market. We do not therefore admit more students than our facilities can accommodate. We invest in facilities to produce graduates that are highly marketable.

Similarly, directors from other community colleges opined that workshops and equipment for training were adequate. The foregoing contradicts the TVET baseline survey finding (Hooker et al., 2011) that equipment in TVET institutions in Kenya are inadequate and obsolete.

The interviews further revealed that community colleges collaborated with local firms to enable students interact with latest technology in the industry. A director emphasised that the college arranged visits to neighboring firms where students would have hand-on experience with latest equipment particularly in electrical installation and dress-making. Another strategy emphatically advanced by the directors was through signing agreements with some workshops and public institutions. This strategy facilitated not only efficient Utilisation of existing physical facilities (such as sports grounds) but also ensured that students had practical sessions for courses with inadequate facilities.

Moreover, the interviews revealed that community colleges co-shared facilities and equipment. This is not only an innovative strategy in overcoming inadequacy of facilities, but also an effective way to stay up-to-date with technology and share costs of 
facilities among institutions involved. However, the co-sharing strategy may not provide students with sufficient time to interact with the facilities thereby hindering their optimal acquisition of practical skills.

Table 2 shows divergent viewpoints of students and teachers with regard to influence of physical facilities on implementation of Artisan and Craft curriculum.

Table 2: Students' and Teachers' Views on Influence Physical Facilities on Curriculum Implementation

\begin{tabular}{lllllllll}
\hline Respondent & \multicolumn{2}{l}{ High Influence } & \multicolumn{2}{l}{ Low Influence } & \multicolumn{2}{l}{ No Influence } \\
& f & \% & f & \% & f & \% & Mean \\
\hline Students & 44 & 30.1 & 70 & 47.9 & 22 & 15.1 & 2.16 \\
Teachers & 11 & 61.1 & 3 & 16.7 & 1 & 5.6 & 2.67 \\
\hline
\end{tabular}

Whereas more students $(47.9 \%)$ rated the influence of physical facilities on implementation of curriculum as low, a large proportion of teachers $(61.1 \%)$ rated it as high. This shows that teachers place high importance on the role of physical facilities in effective implementation to availability of physical facilities than students do, a position supported by the directors who emphasised that adequacy of physical facilities enhanced effective teaching and learning of Artisan and Craft courses.

\subsection{Utilisation of Teaching and Learning Resources in Curriculum Implementation}

The adequacy levels of teaching and learning resources in community colleges were rated by students as shown in Table 3 .

Table 3: Students' Rating of Adequacy of Teaching and Learning Resources

\begin{tabular}{lcccccccccccc}
\hline Resource type & VA & \multicolumn{1}{c}{$\mathbf{A}$} & \multicolumn{4}{c}{ MA } & $\mathbf{I}$ & & VI & & M \\
& $\mathbf{f}$ & $\mathbf{\%}$ & $\mathbf{f}$ & $\mathbf{\%}$ & $\mathbf{f}$ & $\mathbf{\%}$ & $\mathbf{f}$ & $\mathbf{\%}$ & $\mathbf{f}$ & $\mathbf{\%}$ & \\
\hline Raw materials for & & & & & & & & & & & \\
practical & 51 & 34.9 & 27 & 18.5 & 22 & 15.1 & 18 & 12.3 & 24 & 16.4 & 3.44 \\
Reference books & 15 & 10.3 & 20 & 13.7 & 47 & 32.2 & 22 & 15.1 & 32 & 21.9 & 2.74 \\
Course textbooks & 14 & 9.6 & 14 & 9.6 & 43 & 29.5 & 27 & 18.5 & 42 & 28.8 & 2.51 \\
\hline
\end{tabular}

Note: VA = Very Adequate; $\mathrm{A}=$ Adequate; $\mathrm{MA}=$ Moderately Adequate; $\mathrm{I}=$ Inadequate; $\mathrm{VI}=$ Very Inadequate; $\mathrm{M}=$ Mean 
The students' mean ratings revealed that raw materials used in practical training were adequate $(\mathrm{M}=3.44)$. Reference books and laboratories were moderately adequate ( $\mathrm{M}=2.74$ and $\mathrm{M}=2.69$ respectively). However, course textbooks were inadequate $(\mathrm{M}=2.51)$ in community colleges. The implication of this finding is that quality teaching and learning in community colleges is compromised by these inadequacies. Eventually, the low quality training affects student academic achievement hence limits prospects of self-reliance and productivity in the labour market (Onsomu et al., 2009; Yara et al., 2010; Moochi, 2012).

In support of this finding, a director lamented that most textbooks were outdated relative to the changing technology:

"We have a problem with providing current textbooks to students. The textbooks we have were purchased ten years ago. So our students do not get new knowledge from reading them."

This finding corroborates Indosh, et al. (2010) and Mupinga, et al. (2006) findings that TVET institutions lack adequate teaching and learning resources including textbooks and stationery which hinder effective teaching and learning. On the contrary, other directors opined that the teaching and learning resources were underutilised. For instance, a director said that despite adequate provision of raw materials, some teachers spent more time on teaching theory at the expense of practical content. Another reason fronted for underUtilisation of resources was low student enrolment especially in courses for which facilities were provided such as masonry. Whereas underUtilisation of resources due to low student enrolment may not have direct effect, deliberate underUtilisation by teachers is likely to negatively affect the implementation of the Artisan and Craft curriculum. This is because students are eventually exposed to too much theory at expense of practical sessions hence become deficient in application of the theoretical knowledge after graduating.

Table 4 shows divergent viewpoints from students and teachers on influence of teaching and learning resources on implementation of Artisan and Craft curriculum. Both students and teachers rated highly the influence of teaching and learning resources on implementation of curriculum (56.8\% and $66.7 \%$ of students and teachers respectively). This corroborates other documented knowledge that lack of teaching and learning resources hinder the teaching and learning of vocational courses (Mupinga et al., 2006; Daudau, 2010; Bandele \& Faremi, 2012; Hailu, 2011; Hooker et al., 2011; Mupinga, Indoshi et al., 2010). This finding implies that students attribute effective curriculum implementation to teaching and learning resources more than to physical facilities. 
Table 4: Students' and Teachers' Views on Influence Teaching and Learning Resources on Curriculum Implementation

\begin{tabular}{lllllllll}
\hline \multirow{2}{*}{ Respondent } & \multicolumn{2}{l}{ High Influence } & \multicolumn{2}{l}{ Low Influence } & \multicolumn{2}{l}{ No Influence } & \\
& f & \% & f & \% & f & \% & Mean \\
\hline Students & 83 & 56.8 & 48 & 32.9 & 12 & 8.2 & 2.50 \\
Teachers & 12 & 66.7 & 3 & 16.7 & 2 & 11.1 & 2.59 \\
\hline
\end{tabular}

\section{Conclusions and Discussion}

Based on the findings, the study concludes that, while some physical facilities and teaching and learning resources are adequate, their underutilisation and the inadequacy of other core facilities and resources, such as libraries and course textbooks, hinder effective teaching and learning. Although the sharing of facilities and resources with peer institutions and local firms is a commendable strategy, its gains are short-lived. Effective teaching and learning may be hampered by a disrupted learning environment and the anxiety that accompanies such an environment. When the quality of teaching and learning is affected, syllabus coverage is compromised, and students graduate with insufficient mastery of the desired knowledge and competencies. Thus, for effective curriculum implementation, community colleges should not only provide adequate physical facilities and resources, but also optimise the utilisation of these facilities and resources. Finally, a quantitative study on the ratios of facilities and resources to students enrolled in the various courses offered in community colleges may generate a deeper understanding of resource utilisation levels in community colleges.

\section{References}

Afeti, G. (2014). Technical and vocational evaluation and training for industrialisation in Africa. Lagos: Research and Resource Forum.

African Union. (2007). Strategy to revitalize technical and vocational education and training (TVET) in Africa. Addis Ababa: Bureau of the Conference of ministers of Education of the African Union.

Ayuba, U., \& Gatabazi, P. (2010). The role of technical and vocational education and training (TVET) in human resources development: The case of Tumba College of Technology (TCT). Rwanda: Tumba College of Technology.

Bandele, S., \& Faremi, Y. (2012). An investigation into the challenges facing the implementation of technical college curriculum in South West, Nigeria. Journal of Education and Practice, 3(12), 8-13. 
Bartlett, E., Kotrlik, W., \& Higgins, C. (2001). Organizational research: Determining appropriate sample size in survey research. Information Technology, Learning, and Performance Journal, 19(1), 43-50.

Dasman, A. (2011). Challenges facing technical institute graduates in practical skills acquisition in the Upper East Region of Ghana. Asia-Pacific Journal of Cooperative Education, 12(2), 67-77.

Daudau, P. (2010). Teachers' perceptions of outcomes-based science curriculum: A case study from Solomon Islands (Master's Thesis, Victoria University of Wellington, New Zealand).

Ebenehi, A., Rashid, A., Bakar, A. (2016). Predictors of Career Adaptability Skill among Higher Education Students in Nigeria. International Journal For Research In Vocational Education And Training, 3(3), 212-229. doi:10.13152/IJRVET.3.3.3

Hailu, G. (2011). Factors affecting the implementation of technical and vocational and training in selected public institutions of southern zone of Tigray (Master's Thesis, Addis Ababa University). Retrieved from http://etd.aau.edu.et/handle/12345678 9/12689

Hicks, H., Kremer, M., Mbiti, I., \& Miguel, E. (2011).Vocational education voucher delivery and labor market returns: A randomized evaluation among Kenyan youth. Retrieved from http://www.3ieimpact.org/media/filer.../gfr_ow164_vocational_education_in_kenya.pdf

Hooker, E., Mwiyeria, S., Waweru, M., Ocharo, R., Bassi, L., Palmer, D., \& Clark, D. (2011). TIVET ICT baseline survey report 2011: TIVET institutions, Kenya. Retrieved from http://scholar.lib.vt.edu.ezproxy.waikato.ac.nz

Indoshi, C., Wagah, O., \& Agak, O. (2010). Factors that determine students' and teachers' attitudes towards Art and Design curriculum. International Journal of Vocational and Technical Education, 2(1), 9-17.

Kigwilu, P. C. (2014). Determinants of effective implementation of artisan and craft courses in Catholic-sponsored community colleges in Nairobi region (Doctoral dissertation, The Catholic University of Eastern Affrica, Nairobi, Kenya). Retrieved from http://erepo.usiu.ac.ke/bitstream/handle/11732/2820/DOCTORAL\%20DISSERTA TION-PETER\%20CHANGILWA\%20KIGWILU.\%202014.pdf

Korpi, T., De Graaf, P., Hendrick, J., \& Layte, R. (2003). Vocational training and career employment precariousness in Great Britain, the Netherlands and Sweden. Acta Sociologica, 46, 17-30.

Maino, P. (2013). Efforts in reorienting technical vocational education and training (TVET) system in Papua New Guinea (PNG) to the global economy: A case study. In: Achieving vision 2050 through higher education, research, science 83 technology (pp.289-305). Lae, Papua New Guinea: University of Technology.

Messah, O., \& Mucai, G. (2011). Factors affecting the implementation of strategic plans in Government tertiary institutions: A survey of selected technical training institutes. European Journal of Business Management, 3(3), 85-100.

Moochi, O. (2012). Availability, acquisition and Utilisation of instructional resources for teaching Geography in selected secondary schools in Central Kisii District (Master's 
Thesis, Kenyatta University). Retrieved from http://ir-library.ku.ac.ke/handle/123 $456789 / 2626$

Mupinga, M., Busby, R., \& Ngatiah, W. (2006). Postsecondary technical and vocational education institutions in Kenya: Needs and challenges. International Journal of Vocational Education and Training, 14(1), 21-35.

Onsomu, E., Wambugu, A., \& Wamalwa, F. (2009). Improving Technical and Vocational Training in Kenya: Lessons from Selected Countries. KIPPRA Discussion Paper No.105. Nairobi: KIPPRA.

Punch, K. (2009). Introduction to research methods in education. Los Angeles: Sage.

Republic of Kenya. (2012a). Sessional Paper No 14 Reforming education and training sectors in Kenya. Nairobi: Government Press.

Republic of Kenya. (2012b). Task force on educational reforms. Nairobi: Government Printers.

Sharma, A. (2008). Technical vocational education and training: The master key. The Review of the Functions of FIT, TPAF and other TVET Providers. Fiji: Ministry of Education, Youth and Sports, Arts, Culture \& National Heritage.

Simiyu, W. (2009). Revitalizing a technical training institute in Kenya: A case study of Kaiboi technical training institute, Eldoret, Kenya. Bonn, Germany: UNESCOUNEVOC International Centre for Technical and Vocational Education and Training. Retrieved from http://www.unevoc.unesco.org/publications

Taskforce Report. (2012). Taskforce on the re-alignment of the education sector to the Constitution of Kenya. Nairobi: Government Printer.

Tshabalala, T., \& Ncube, C. (2014). Teachers' perceptions on challenges faced by rural secondary schools in the implementation of the technical and vocational education and training policy in Nkayi district. International Research Journal of Teacher Education, 1(2), 10-15.

Umunadi, K. (2012). Resource management and planning in vocational and technical education for national development: An assessment. African Journal of Educational Technology, 2(1), 48-59.

UNESCO, (2010). Reaching the marginalized: EFA global monitoring report 2010. Paris and London: UNESCO Publishing and Oxford University Press.

Wondaferew, A. (2012). Factors influencing the quality of training: Technical and vocational education in Addis Ababa. Korea Review of International Studies, 15(1), 49-63.

Yara, P., \& Otieno, K. (2010). Teaching/learning instructional resources and academic performance in mathematics in secondary schools in Bondo District of Kenya. Asian Social Science, 6(12), 126-132.

\section{Biographical Notes}

Dr Peter Changilwa Kigwilu is a Curriculum Developer at the United States International University-Africa, Kenya. He holds a PhD in Education (Curriculum Studies and Instruction). His research interests include but are not limited to curriculum innovations; 
school improvement and effectiveness, Technical and Vocational Education and Training (TVET), teacher education, technology in education, monitoring and evaluation. His publications comprise ten journal articles, two books, three book chapters, two university level modules and seven international conference papers.

Dr Winston Jumba Akala is the Dean, School of Education, of the University of Nairobi, Kenya. He is a Fulbright Scholar and Associate Professor of research and statistics in education. He has vast experience in research and training, higher education curriculum design, and teacher education. 